\title{
Preventive Health in Cancer Survivors: What Should We Be Recommending?
}

\author{
Linda S. Overholser, MD, MPH, a, and Carlin Callaway, DNPa,c
}

\begin{abstract}
Individuals with a history of cancer, often referred to as cancer survivors, may experience late and long-term effects of their treatment. Because these individuals live longer in the survivorship phase, some of these late effects may also be considered risk factors for other chronic conditions. With cancer and cardiovascular disease now the top 2 leading causes of death in the United States and with common risk factors for both, as well as the morbidity that can occur after cancer treatment, preventive health is becoming an important issue in cancer survivorship care. Multimorbidity is also becoming increasingly commonplace. Along with an ever-expanding number of guidelines available to help guide care and treatment in the noncancer population comes the need to consider where these guidelines overlap or intersect when considering preventive health recommendations specific to cancer survivors. Counseling for health promotion in survivors is lacking. Many currently available guidelines may not apply to this population, and an evidence base is building to help supplement clinical judgement. An interdisciplinary approach will be necessary to help implement preventive care decision-making early in the survivorship trajectory and to ensure that cancer survivors are receiving consistent messages, and patient preferences and priorities should be taken into account when doing so. Incorporating preventive health into collaborative survivorship care can help maintain a high quality of life for individuals living after a cancer diagnosis.
\end{abstract}

J Natl Compr Canc Netw 2018;16(10):1251-1258 doi: 10.6004/jnccn.2018.7083

An increasing number of people are presenting to their healthcare providers (HCPs) with a history of cancer. As of January 2016, there were 15.5 million Americans living with a history of cancer. ${ }^{1}$ Bluethmann et $\mathrm{al}^{2}$ predict that 26.1 million survivors will be living in 2040 and that $47 \%$ will live $>10$ years after their diagnosis. In 2018, an estimated 1.7 million new cases of cancer will be diagnosed and 609,400 people will die of their disease; however, the overall death rate from cancer has decreased $26 \%$ over the past 3 decades, which translates into 2.4 million fewer cancer-related deaths. ${ }^{3}$

Although these trends speak to the successes in the areas of early detection, screening, and treatment, the phase of cancer care recognized as survivorship ${ }^{4}$ - from the time of diagnosis through the end of life-brings

aniversity of Colorado Cancer Center, and 'bivision of General Internal Medicine and 'Division of Medical Oncology, University of Colorado Denver School of Medicine, Aurora, Colorado.

Submitted June 22, 2018; accepted for publication September 10, 2018.

Dr. Overholser has disclosed that her spouse owns stock in Amgen, Celgene, and GlaxoSmithKline. Dr. Callaway has disclosed that she has with it emerging and unique challenges for patients, HCPs, and the healthcare system. An individual living in the survivorship phase of cancer not only may need to manage the various potential late and long-term effects of treatment but also may over time need to shift their focus back to primary prevention or management of other medical conditions, which still includes cancer prevention. According to data within the SEER program of cancer registries, of 765,843 incident cancers diagnosed between 2009 and 2013, approximately one-fourth of adults aged $\geq 65$ years and just more than one-tenth of younger adults aged 20 to 64 years were experiencing their second or higher tcancer. ${ }^{5}$ Most of these new cancers (termed second primary cancers) were diagnosed in different anatomic locations. These cancers randomly

no financial interests, arrangements, affiliations, or commercial interests with the manufacturers of any products discussed in this article or their competitors.

Correspondence: Linda S. Overholser, MD, MPH, Division of General Internal Medicine, University of Colorado Denver School of Medicine, 12631 East 17th Avenue, Mail Stop B180, Aurora, CO 80045.

Email: Linda.overholser@ucdenver.edu 
developed, resulted from behaviors (ie, smoking), or occurred because of inherited mutations.

It is also worth considering other major causes of morbidity and mortality after a cancer diagnosis. As the leading all-cause of death for both men and women, ${ }^{6}$ cardiovascular disease (CVD) rises to the top as a major threat to the health of survivors. CVD, known to be the major cause of death for adults in the US general population, is now known to be a leading cause of death in individuals treated for cancer. ${ }^{7-12}$ As with cancer, CVD in survivors could be due to common behavioral risk factors, a family history, a late effect of cancer therapies, or a combination thereof. Some late effects may be considered risk factors for noncancer conditions, such as ischemic heart disease or stroke.

Modifiable risk factors, such as lack of physical activity, hypertension, dyslipidemia, obesity, diabetes mellitus, unhealthy dietary habits, and smoking, contribute not only to CVD but also to cancer, and can also impact the course of cancer survivorship. These risk factors are also targets of preventive health counseling, screening, and care. As such, both oncology and primary care teams have important roles in the preventive care of cancer survivors. The aim of this review is to highlight examples of preventive health recommendations for survivors, emphasizing CVD given its prevalence in the US population and in primary care practice, and to stimulate thought regarding how oncology teams can partner with primary care colleagues to ensure preventive care is being appropriately delivered. It is beyond the scope of this review to discuss comprehensive preventive health recommendations for every combination of cancer type, sex, treatment exposure, and comorbid condition, but an overview of considerations is presented.

\section{Defining Preventive Care}

The goal of preventive care is to prevent morbidity and mortality in individuals, including both physical and psychosocial. For individuals at risk for or who have been diagnosed with cancer, recent trends in increasing survival rates are encouraging and to some extent attributable to preventive health activities, such as cancer screening, chemoprevention, testing, and behavioral counseling to reduce known risk factors. To leverage the gains made in cancer treatment and survival, we should not limit the con- cept of preventive care to reducing the incidence of cancer. We now have the means and an evidence base with which to extend the concept of preventive health beyond preventing a cancer diagnosis. In fact, a cancer diagnosis has been described as a "teachable moment" for health promotion. ${ }^{13,14}$

To review how preventive health could apply to cancer survivors, consider the traditional layers of preventive care: primary, secondary, and tertiary. Primary prevention has the goal of reducing the risk of a condition ever developing; secondary prevention is intended to detect a condition at an asymptomatic or early stage when opportunities for intervention would be favorable; and tertiary prevention then seeks to reduce the severity and complications of a condition. For patients with a history of cancer, all of these conditions still apply, but with the additional layer that an individual's cancer treatment may itself confer a new set of health risks to consider when engaging in preventive health activities. For cancer survivors, then, these levels of preventive care may overlap. ${ }^{14}$ The potential late and long-term effects of cancer treatment include conditions, such as CVD, for which preventive strategies exist and behavioral risk factors may influence both cancer survival and comorbid conditions.

\section{Risk-Based Care}

The concept of risk-based care in cancer is not necessarily a new one,${ }^{15}$ but is especially relevant when discussing preventive care for cancer survivors. With the increasing array of cancer treatments available, including newer targeted and immune therapies, important health risks attributable to these treatments should be identified when known, and communicated to both patients and primary care teams.

\section{Multimorbidity}

Individuals with multiple chronic medical conditions are becoming the norm in healthcare, and strategies to counsel patients and recommendations from HCPs will need to account for this. ${ }^{8,16}$ Preexisting comorbid conditions may negatively impact patients' ability to receive curative treatment for a new cancer, and cancer treatment itself can be associated with late effects or worsening of comorbid conditions. ${ }^{17}$ An analysis of Medicare beneficiaries revealed that $40 \%$ of cancer survivors had $\geq 1$ 
chronic health condition and $15 \%$ had $\geq 2$ chronic health conditions. ${ }^{18}$ Adults with a history of childhood cancer are more likely than their age-matched peers to have significant chronic medical conditions and to develop them at a younger age. ${ }^{19-21}$ The clinical effects of cancer treatment have been postulated to be similar to aging processes occurring at cellular levels, and aging pathways may impact late complications for survivors. ${ }^{22}$ Research in the area of multimorbidity clinical care is lacking, ${ }^{23}$ but on a more practical level, some studies have acknowledged that the clinical challenges of caring for individuals with multiple chronic medical conditions are significant both for patients and HCPs. ${ }^{24-26}$ Some of this may be attributable to the fact that most clinical practice guidelines are disease-specific and do not take into consideration other recommendations that may apply to comorbid conditions. ${ }^{25}$ Likewise, guidelines may not take into account patient preferences, priorities, or available resources. Notably, of the studies mentioned that discuss multimorbidity, none included cancer as a chronic condition.

\section{Counseling for Health Promotion}

Although the benefits of lifestyle modification to reduce cancer risk are well-known, counseling for health promotion in cancer survivors does not always occur. Individuals with a history of cancer are not necessarily faring better than their peers without cancer when it comes to meeting current recommendations for healthy behaviors, ${ }^{27-30}$ but cancer survivors do want and appreciate this counseling. ${ }^{31}$ Receipt of health behavior counseling could vary based on type of HCP seen, cancer type and stage, and patient characteristics. For example, a 2009 survey of colorectal cancer survivors reported that discussions around health promotion and diet were more likely to occur during visits with primary care providers than with oncologists, but for cancer surveillance the converse was true. ${ }^{32} \mathrm{~A}$ separate study of colorectal and lung cancer survivors reported that younger and higher-educated survivors were more likely to have received health behavior counseling from any physician in the previous year, and that chances of this happening were also higher in those with comorbidities, such as diabetes or high blood pressure. ${ }^{33}$ Cancer survivorship care plans could play an important role in emphasizing the need for preventive care.

\section{Guidance for Preventive Health in Cancer Survivors}

The combination of increasing survival rates with the identification of late and long-term effects challenges healthcare teams to provide high-value, appropriate care to reduce the overall burden from cancer. Numerous guidelines from well-respected organizations provide recommendations based on randomized controlled trials, nonrandomized control studies, and/or expert consensus opinion that may apply to patients with cancer or to preventive health in general, but only a handful of these focus explicitly on cancer survivorship (supplemental eTable 1, available with this article at JNCCN.org). ${ }^{34-41}$ Primary care guidelines are often population-focused and are intended for use across the lifespan for preventive care; recommendations that do not focus on the cancer continuum may not be familiar to healthcare teams who primarily treat cancer. Oncology guidelines are often individually focused and intended to help guide cancer diagnosis, treatment, and surveillance; treatment regimens and associated late and long-term toxicities may not be familiar to primary care. The complexity of preventive care for cancer survivors calls for collaboration and clear communication between primary care and oncology teams. This involves choosing and applying the most appropriate guidelines for any one individual. However, such communication and collaboration has proven to be a difficult goal to achieve, ${ }^{42}$ and there is not uniform agreement on who should be providing the bulk of survivorship care. ${ }^{42,43}$ In a small study of Canadian family physicians and primary health practitioners, breast cancer survivorship guideline recommendations that focused on preventive health were implemented at higher rates than those focusing on other aspects of survivorship care, ${ }^{44}$ but gaps did exist across the board.

\section{Review of Preventive Recommendations}

A detailed description of all late and long-term effects of treatment for all cancer types is beyond the scope of this review. However, it is worthwhile to highlight a few representative conditions, especially those for which the evidence base may intersect with currently available survivorship guidelines. A comprehensive preventive health examination or survivorship visit would be an ideal time to sys- 
tematically think about how health promotion and screening recommendations might need to be modified (or not) given an individual's cancer history. A survivorship-focused review of systems as one way to systematically identify potentially significant physical late and long-term effects, described by Ganz $z^{45}$ in 2006, is helpful because it is consistent with routine clinical practice. Using a review of systems to also consider targets for preventive health recommendations is similarly a practical way to approach the topic and could provide common ground for primary, oncology, or other healthcare teams (eg, cardiology, endocrinology) caring for survivors. Table 1 includes examples of the additional layer of recommendations that may be applied for an individual with a cancer history when presenting for preventive care; this list should not be considered exhaustive. Due to the limited evidence base for preventive care in survivors, the best health promotion strategy may be to apply general preventive health recommendations and to have a lowered index of suspicion for a target condition to enable earlier diagnosis.

\section{CVD and CVD Risk Factors: Example of Hypertension}

Of the systems to consider in applying preventive health recommendations, the one for which there is perhaps the greatest potential to impact overall morbidity and mortality for cancer survivors is CVD and its associated risk factors. NCCN and the Children's Oncology Group (COG) have guidelines that address anthracycline-induced cardiac toxicity $\left(\mathrm{NCCN},{ }^{36}\right.$ COG) and other CVDs (COG). ${ }^{35}$ The American Heart Association (AHA) recently released a scientific statement on the intersection of breast cancer and $\mathrm{CVD}^{46}$ that emphasizes the importance of assessing CVD risk early in the survivorship phase.

Individuals who have received potentially cardiotoxic cancer therapies may be considered to be at high risk for heart failure and could even be con-

Table 1. Preventive Care and Additional Considerations for Individuals With a History of Cancer

\begin{tabular}{|c|c|c|c|}
\hline Body System & $\begin{array}{l}\text { Conditions for Which } \\
\text { Preventive Strategies Exist, } \\
\text { General Population }\end{array}$ & $\begin{array}{l}\text { Additional Preventive and Screening } \\
\text { Considerations for Cancer Survivors }\end{array}$ & $\begin{array}{l}\text { Comments and Examples of Guidelines or Recommendations } \\
\text { That Might Apply }\end{array}$ \\
\hline $\begin{array}{l}\text { Head, ears, } \\
\text { nose, throat }\end{array}$ & $\begin{array}{l}\text { Oral cancer screening } \\
\text { Dental cleanings twice yearly }\end{array}$ & $\begin{array}{l}\text { Xerostomia } \\
\text { Osteonecrosis of the jaw } \\
\text { Hearing loss screening }\end{array}$ & $\begin{array}{l}\text { May require more frequent dental examinations/cleanings and input from } \\
\text { dental team, especially if xerostomia is present; need to address use of tobacco } \\
\text { products and smoking cessation if still smoking (ADA, COG) }\end{array}$ \\
\hline Eyes & Glaucoma screening & $\begin{array}{l}\text { Cataracts after anticancer } \\
\text { medications } \\
\text { Eye dryness } \\
\text { Ocular toxicity }\end{array}$ & Examination can screen for cataracts (AAO) \\
\hline Cardiovascular & $\begin{array}{l}\text { Risk factor identification and } \\
\text { management } \\
\text { Hypertension } \\
\text { Lipid levels } \\
\text { Weight } \\
\text { Family history } \\
\text { Smoking } \\
\text { Abdominal aortic aneurysm } \\
\text { screening in high-risk } \\
\text { individuals }\end{array}$ & $\begin{array}{l}\text { Premature ASCVD } \\
\text { Myocarditis } \\
\text { Pericarditis } \\
\text { Stroke } \\
\text { Chemotherapy-induced } \\
\text { cardiomyopathy } \\
\text { Risk of lipid, blood pressure } \\
\text { derangement with therapies }\end{array}$ & $\begin{array}{l}\text { Possible role for periodic echocardiographic surveillance for chemotherapy- } \\
\left.\text { induced cardiomyopathy (COG, NCCN, }{ }^{36} \mathrm{ASCO}\right) \text {; length of follow-up unclear; } \\
\text { screen for symptoms and have low index of suspicion for suggestive symptoms } \\
\text { of cardiomyopathy } \\
\text { No definitive evidence on role of } \beta \text {-blockers and ACE inhibitors in preventing } \\
\text { cardiomyopathy in asymptomatic individuals } \\
\text { Unclear role of aspirin for primary prevention in cancer survivors } \\
\text { Exposure to cardiotoxic therapies may be considered stage A heart failure } \\
\text { (NCCN, }{ }^{36} \text { ACC/AHA) } \\
\text { Traditional risk factors should be managed proactively per ACC/AHA } \\
\text { guidelines; may need to be reviewed more frequently than otherwise } \\
\text { recommended for general population } \\
\text { General recommendation to encourage regular physical activity/avoiding } \\
\text { inactivity and maintaining a healthy diet (ACSM, ACS, NCCN }{ }^{36} \text { )-may also help } \\
\text { reduce CVD risk } \\
\text { Need to consider CVD at a lower threshold in survivors presenting with } \\
\text { symptoms }\end{array}$ \\
\hline Pulmonary & $\begin{array}{l}\text { Lung cancer screening for } \\
\text { smokers } \\
\text { Counseling for smoking } \\
\text { cessation }\end{array}$ & $\begin{array}{l}\text { Bleomycin toxicity } \\
\text { Lung fibrosis } \\
\text { Pneumocystis } \\
\text { Pneumonitis } \\
\text { Possible secondary pulmonary } \\
\text { cancer? }\end{array}$ & $\begin{array}{l}\text { Need to ensure that smoking cessation counseling is provided for all smokers } \\
\text { For those having received bleomycin, avoid high-flow oxygen if possible or } \\
\text { minimize exposure if needed (ie, surgery) (COG) } \\
\text { No routine x-ray surveillance/screening, but consider baseline at entry into } \\
\text { follow-up if past receipt of XRT }\end{array}$ \\
\hline $\begin{array}{l}\text { Gastrointestinal } \\
\text { and hepatic }\end{array}$ & $\begin{array}{l}\text { Colon cancer screening } \\
\text { Age-specific HCV screening }\end{array}$ & $\begin{array}{l}\text { Colitis/Proctitis } \\
\text { Iron overload if history of blood } \\
\text { transfusions } \\
\text { Possible increased risk for colon } \\
\text { cancer if history of abdominal/pelvic } \\
\text { XRT }\end{array}$ & $\begin{array}{l}\text { Colorectal cancer screening may need to be considered at earlier ages and/or } \\
\text { more frequently for individuals with hereditary cancer syndromes or who have } \\
\text { received abdominal XRT (COG) } \\
\text { Consider baseline HCV screening if received blood transfusion/transplantation } \\
\text { before } 1992\end{array}$ \\
\hline
\end{tabular}

Abbreviations: AAD, American Academy of Dermatology; AAO, American Academy of Ophthalmology; ACC/AHA, American College of Cardiology/American Heart Association; ACE, angiotensin-converting enzyme; ACIP, Advisory Committee on Immunization Practices; ACS, American Cancer Society; ACSM, American College of Sports Medicine; ADA, American Dental Association; ASCVD, atherosclerotic CVD; CNS, central nervous system; COG, Children's Oncology Group; CVD, cardiovascular disease; GVHD, graft-versus-host disease; HCV, hepatitis C virus; POF, premature ovarian failure; PTSD, posttraumatic stress disorder; XRT, radiotherapy. 


\begin{tabular}{|c|c|c|c|}
\hline Body System & $\begin{array}{l}\text { Conditions for Which } \\
\text { Preventive Strategies Exist, } \\
\text { General Population }\end{array}$ & $\begin{array}{l}\text { Additional Preventive and Screening } \\
\text { Considerations for Cancer Survivors }\end{array}$ & $\begin{array}{l}\text { Comments and Examples of Guidelines or Recommendations } \\
\text { That Might Apply }\end{array}$ \\
\hline Genitourinary & Prostate cancer screening & $\begin{array}{l}\text { Bladder cancer? } \\
\text { Renal insufficiency } \\
\text { Radiation cystitis } \\
\text { Single kidney precautions }\end{array}$ & $\begin{array}{l}\text { Low threshold to check urinalysis, cytology if bleeding, and past exposure to } \\
\text { alkylating agents } \\
\text { Precautions for those who have nephrectomy/single kidney precautions (eg, } \\
\text { avoid nonsteroidal anti-inflammatory drugs, contact sports) }\end{array}$ \\
\hline $\begin{array}{l}\text { Sexual and } \\
\text { reproductive } \\
\text { health }\end{array}$ & $\begin{array}{l}\text { Sexually transmitted } \\
\text { infection screening } \\
\text { Breast cancer screening } \\
\text { Cervical cancer screening }\end{array}$ & $\begin{array}{l}\text { Infertility/Family planning } \\
\text { POF } \\
\text { Hypogonadism }\end{array}$ & $\begin{array}{l}\text { Inquire about late/long-term effects of treatment, including sexual side effects; } \\
\text { this is a gap in care (NCCN }{ }^{36} \text { ) } \\
\text { Semen analysis, infertility evaluation for young adults with cancer history; } \\
\text { caution patients that in some cases fertility may return, counsel regarding safe } \\
\text { sex practices and unintended pregnancies, and that normal menses do not } \\
\text { necessarily equate with preserved fertility } \\
\text { Proactive referral for fertility assessment } \\
\text { Clinical history and symptom screening for hypogonadism/POF; pursue testing } \\
\text { if clinical history/symptoms suggest }\end{array}$ \\
\hline Neurologic & $\begin{array}{l}\text { Stroke risk factor } \\
\text { identification and } \\
\text { management (see } \\
\text { Cardiovascular) }\end{array}$ & $\begin{array}{l}\text { Carotid artery disease } \\
\text { Cognitive changes (eg, thinking, } \\
\text { memory, learning) } \\
\text { Peripheral neuropathy } \\
\text { Secondary CNS tumors (eg, } \\
\text { meningiomas from cranial XRT) }\end{array}$ & $\begin{array}{l}\text { Regular assessments and low threshold to workup symptoms of carotid artery } \\
\text { disease if history of neck/cranial XRT } \\
\text { No routine brain imaging recommendation for secondary CNS tumors; depends } \\
\text { on dose of XRT received, but need to have low index of suspicion if any new } \\
\text { neurologic symptoms (COG) }\end{array}$ \\
\hline Skin & $\begin{array}{l}\text { Skin cancer prevention } \\
\text { counseling }\end{array}$ & $\begin{array}{l}\text { GVHD } \\
\text { Increased risk for skin cancer in areas } \\
\text { of radiation }\end{array}$ & $\begin{array}{l}\text { In the sun, survivors should apply and reapply SPF } \geq 30 \text { sunscreen every } 2 \text { hours } \\
\text { (or after swimming and perspiring), seek shade, and wear protective clothing } \\
\text { to cover as much of their bodies as possible (NCCN }{ }^{36} \text { ) } \\
\text { Self-examinations of skin and awareness of the potential for reflection around } \\
\text { sand, snow, and water (ACS, AAD) } \\
\text { Annual skin examination; low threshold to refer if any skin changes in field of } \\
\text { radiation } \\
\text { GVHD can affect multiple organs other than skin; need low index of suspicion } \\
\text { for bone marrow transplant recipients }\end{array}$ \\
\hline Psychosocial & Depression screening & $\begin{array}{l}\text { Anxiety } \\
\text { Distress } \\
\text { Fear of recurrence } \\
\text { PTSD } \\
\text { Vocational } \\
\text { Educational/Neurocognitive } \\
\text { impairment } \\
\text { Financial toxicity } \\
\text { Gaps in access to healthcare }\end{array}$ & $\begin{array}{l}\text { Periodic assessments include Patient Health Questionnaire (PHQ)-2 or -9 and } \\
\text { Generalized Anxiety Disorder (GAD)-7 scales, but need to consider other } \\
\text { diagnoses with history of cancer (eg, adjustment disorder, PTSD) } \\
\text { Oncology settings may use distress screening tool (NCCN }{ }^{36} \text { ) }\end{array}$ \\
\hline $\begin{array}{l}\text { Immunologic/ } \\
\text { Infectious }\end{array}$ & $\begin{array}{l}\text { Age-appropriate } \\
\text { vaccinations } \\
\text { HIV screening }\end{array}$ & $\begin{array}{l}\text { Post bone marrow/stem cell } \\
\text { transplant vaccinations } \\
\text { Splenectomy precautions }\end{array}$ & $\begin{array}{l}\text { After bone marrow transplant, will need revaccination }\left(\mathrm{NCCN}^{36}\right) \\
\text { For adults with splenectomy, no routine antibiotic prophylaxis, but any fever } \\
\text { must be evaluated immediately and empiric therapy initiated right away } \\
\text { For adults with splenectomy, altered vaccination schedule for pneumococcal, } \\
\text { meningococcal, haemophilus vaccines (ACIP) } \\
\text { If immune-suppressed, avoid live virus vaccines }\left(\mathrm{NCCN}^{36}\right)\end{array}$ \\
\hline Hematologic & & $\begin{array}{l}\text { Anemia } \\
\text { Chronic GVHD } \\
\text { Secondary leukemia }\end{array}$ & $\begin{array}{l}\text { Some risk of secondary leukemia with alkylating agents; risk decreases over } \\
\text { time after exposure }\end{array}$ \\
\hline Endocrine & $\begin{array}{l}\text { Diabetes screening } \\
\text { Management of prediabetes/ } \\
\text { diabetes } \\
\text { Screening diabetic } \\
\text { retinopathy } \\
\text { Screening for neuropathy } \\
\text { Screening for microvascular } \\
\text { renal disease } \\
\text { Osteoporosis }\end{array}$ & $\begin{array}{l}\text { Hyperglycemia and early-onset } \\
\text { diabetes } \\
\text { Adrenal insufficiency } \\
\text { Hypogonadism } \\
\text { Hypopituitarism } \\
\text { Hypothyroidism } \\
\text { Menopause/POF } \\
\text { Growth hormone deficiency } \\
\text { Thyroid cancer }\end{array}$ & $\begin{array}{l}\text { Adult survivors (aged }>21 \text { years) of pediatric/adolescent cancer who received } \\
\text { cranial or abdominal XRT may be at increased risk for early development of } \\
\text { diabetes and metabolic syndrome (COG) } \\
\text { Need to have low index of suspicion for hypogonadism, test if symptoms } \\
\text { suggest } \\
\text { Role of growth hormone therapy in most adults unclear } \\
\text { Weight gain and lack of physical activity are risk factors for diabetes; need to } \\
\text { ensure all survivors who are not underweight are receiving recommendations } \\
\text { for preventing weight gain (NCCN }{ }^{36} \text { ) } \\
\text { Patients with a history of XRT to the neck are at increased risk for thyroid } \\
\text { nodules and cancer; annual neck examination and history can help diagnose; } \\
\text { no role for routine neck ultrasound if no nodules/symptoms }\end{array}$ \\
\hline Musculoskeletal & Overall functional & $\begin{array}{l}\text { Avascular necrosis } \\
\text { Deconditioning } \\
\text { Range-of-motion changes } \\
\text { Prostheses } \\
\text { Lymphedema }\end{array}$ & $\begin{array}{l}\text { Cancer rehabilitation programs can be very helpful with directed } \\
\text { recommendations for cancer survivors } \\
\text { Need low index of suspicion for avascular necrosis; no routine testing } \\
\text { No role for routine use of antibiotic prophylaxis in lymphedema; some physical } \\
\text { therapists are certified in lymphedema management }\end{array}$ \\
\hline $\begin{array}{l}\text { General/ } \\
\text { Constitutional/ } \\
\text { Multiple } \\
\text { systems }\end{array}$ & $\begin{array}{l}\text { Lifestyle counseling } \\
\text { Physical activity } \\
\text { Nutrition } \\
\text { Sunscreen } \\
\text { Smoking } \\
\text { Pain screening }\end{array}$ & $\begin{array}{l}\text { Fatigue } \\
\text { Identification of hereditary cancer } \\
\text { mutations and syndromes } \\
\text { Nutrition (weight loss or gain } \\
\text { following treatment) } \\
\text { Past and current opioid use } \\
\text { Sleep disorder }\end{array}$ & $\begin{array}{l}\text { Healthy lifestyle recommendations for noncancer population generally apply } \\
\text { to most long-term cancer survivors (NCCN, }{ }^{36} \text { ACS, ASCO, COG, ACSM) } \\
\text { Goal is to perform } 150 \text { minutes of moderate exercise each week ( } 75 \text { minutes } \\
\text { vigorous activity) if functional status allows; avoid prolonged periods of sitting; } \\
\text { and seek, achieve, and maintain a healthy body mass index } \\
\text { Alcohol use has been associated with reduced survival in some cancers and is } \\
\text { also a risk factor for some cancers } \\
\text { Well-balanced meals should include decreased amounts of red/processed meat, } \\
\text { increased quantities of vegetables, fruits, and whole grains } \\
\text { Need to ensure that opioids, if needed during treatment, are appropriately } \\
\text { reviewed and tapered if appropriate } \\
\text { Supplements in general not recommended for routine use and some can have } \\
\text { risks; need to assess for use regularly }\end{array}$ \\
\hline
\end{tabular}

Abbreviations: AAD, American Academy of Dermatology; AAO, American Academy of Ophthalmology; ACC/AHA, American College of Cardiology/American Heart Association; ACE, angiotensin-converting enzyme; ACIP, Advisory Committee on Immunization Practices; ACS, American Cancer Society; ACSM, American College of Sports Medicine; ADA, American Dental Association; ASCVD, atherosclerotic CVD; CNS, central nervous system; COG, Children's Oncology Group; CVD, cardiovascular disease; GVHD, graft-versus-host disease; HCV, hepatitis C virus; POF, premature ovarian failure; PTSD, posttraumatic stress disorder; XRT, radiotherapy. 
sidered to have asymptomatic heart failure. ${ }^{47}$ Use of specific agents to prevent the development of cardiomyopathy related to cancer treatment is mixed, ${ }^{48}$ with some evidence supporting the use of dexrazoxane and potentially $\beta$-blockers. Once treatment is completed, scant evidence supports the use of any agent specifically to reduce the risk of CVD in survivors, with AHA recommending following currently available population-based recommendations for the primary prevention of CVD. ${ }^{46}$

The key may be to proactively identify CVD risk factors and coordinate care in such a way that comorbid risk factors are addressed. Using the example of hypertension as a known risk factor for CVD, the US Preventive Services Task Force (USPSTF) recommends screening adults aged $\geq 18$ years for hypertension. ${ }^{49}$ This recommendation applies to the general adult population (aged $>18$ years) with no previous history of hypertension. For this population, recommended intervals are every 3 to 5 years for adults aged 18 to 39 years with normal blood pressure (defined as $<130 / 85 \mathrm{~mm} / \mathrm{Hg}$ ) or yearly for adults aged $>40$ years. Although there is no mention specifically of cancer survivors, language in the recommendation allows for variance for individuals at "increased risk," such that those aged $<40$ years who may have elevated risk should be assessed at yearly intervals. ${ }^{49}$ This would be an important consideration in adolescent and young adult cancer survivors (aged 15-39 years), for example, who have received cancer treatments or who have experienced sequelae such as weight gain that could increase their risk of CVD but are otherwise asymptomatic, because individuals in this age group may not be aware of the need for this type of screening. Likewise, HCPs of these individuals need to be aware that past cancer treatments may confer additional risk for CVD, and should incorporate strategies to proactively manage these risks while recognizing limitations of currently available guidelines. Again, using the example of hypertension in the primary care setting, recommendations and approaches from other organizations exist and may vary slightly from the USPSTF, such as those from the $\mathrm{AHA}^{50}$ or the American College of Obstetricians and Gynecologists ${ }^{51}$; the American Academy of Family Physicians endorses the USPSTF recommendations. ${ }^{52}$ The most recently published guidelines from the Eighth Joint National Committee for the management of hypertension and other conditions state that blood pressure goals may vary depending on patient age and presence of comorbid conditions, such as chronic kidney disease, diabetes, and CVD, but not specifically cancer, although do allow for consideration of those at elevated risk of CVD, which could include those with past cancer treatment. ${ }^{53,54} \mathrm{~A}$ more recent meta-analysis of nearly 50,000 participants suggests that using an approach to managing blood pressure based on risk for developing CVD may be more efficient than using numerical thresholds ${ }^{55}$; this was especially evident for individuals without established CVD or diabetes. Updated guidelines reflect this approach ${ }^{50,56}$ and address detailed strategies to manage high blood pressure, ${ }^{50}$ although whether this approach applies to the risk that may be conferred specifically from cancer treatment is unknown. This discussion of the evolving strategy to manage a single risk factor that could also be a late effect of treatment highlights the complexity of providing preventive care recommendations for cancer survivors and is an example of a needed area of collaborative research.

\section{Conclusions}

Reducing the overall morbidity and mortality burden related to a cancer diagnosis requires consideration of the associated late and long-term effects of treatment, some of which may be risk factors for disease. Healthcare professionals involved in the diagnosis, treatment, and follow-up for cancer will need to work together across disciplines to implement appropriate recommendations and counseling to achieve this goal. For oncology teams actively involved in cancer treatment or follow-up, this may mean incorporating a dedicated focus on long-term preventive health strategies early in the survivorship phase and outlining risks to long-term health at the time of transition to primary care. For primary care teams, this may mean conceptualizing cancer as a chronic condition and developing familiarity with late and long-term effects of cancer treatment as targets for counseling and prevention. For both, clear communication will be required between these teams and any others involved to avoid unnecessary duplication of efforts or resources, while at the same time ensuring that appropriate recommendations are being applied. Whenever possible, the names of specific guidelines should be used. Interdisciplinary ef- 
forts mean that all disciplines (eg, oncology, primary care, cardiology, endocrinology, behavioral health) should be prepared to address each patient's preferences and priorities for care in a consistent way. Because the current evidence base for preventive care in survivors is limited, how preventive care is imple- mented is as valid a question as what to implement. Taking a good cancer-focused history and assessing for late and long-term effects will go a long way toward filling gaps. The end goal of these efforts is to give a high quality to the extended life that is now possible through advances in treatment.

\section{References}

1. Miller KD, Siegel RL, Lin CC, et al. Cancer treatment and survivorship statistics, 2016. CA Cancer J Clin 2016;66:271-289.

2. Bluethmann SM, Mariotto AB, Rowland JH. Anticipating the 'silver tsunami': prevalence trajectories and co-morbidity burden among older cancer survivors in the United States. Cancer Epidemiol Biomarkers Prev 2016;25:1029-1036.

3. Siegel RL, Miller KD, Jemal A. Cancer statistics, 2018. CA A Cancer J Clin 2018;68:7-30.

4. Hewitt M, Greenfield S, Stovall E. From Cancer Patient to Cancer Survivor: Lost in Transition. Washington, DC: National Academies Press; 2005.

5. Murphy CC, Gerber DE, Pruitt SL. Prevalence of prior cancer among persons newly diagnosed with cancer: an initial report from the Surveillance, Epidemiology, and End Results program. JAMA Oncol 2018;4:832-836.

6. Kochanek KD, Murphy SL, Xu JQ, Arias E. Mortality in the United States, 2016. NCHS Data Brief 2017:1-8.

7. Patnaik JL, Byers T, DiGuiseppi C, et al. Cardiovascular disease competes with breast cancer as the leading cause of death for older females diagnosed with breast cancer: a retrospective cohort study. Breast Cancer Res 2011;13:R64.

8. Bayliss EA, Reifler LM, Zeng C, et al. Competing risks of cancer mortality and cardiovascular events in individuals with multimorbidity. J Comorb 2014;4:29-36.

9. Gernaat SA, Ho PJ, Rijnberg N, et al. Risk of death from cardiovascular disease following breast cancer: a systematic review. Breast Cancer Res Treat 2017;164:537-555.

10. Armstrong GT, Oeffinger KC, Chen Y, et al. Modifiable risk factors and major cardiac events among adult survivors of childhood cancer. J Clin Oncol 2013;31:3673-3680.

11. Oeffinger KC, Mertens AC, Sklar CA, et al. Chronic health conditions in adult survivors of childhood cancer. N Engl J Med 2006;355:1572-1582.

12. van Nimwegen FA, Schaapveld M, Janus CP, et al. Cardiovascular disease after Hodgkin lymphoma treatment: 40 year risk. JAMA Int Med 2015;175:1007-1017.

13. Mcbride CM, Ostroff JS. Teachable moments for promoting smoking cessation: the context of cancer care and survivorship. Cancer Control 2003;10:325-333.

14. Demark-Wahnefried W, Aziz NM, Rowland JH, Pinto BM. Riding the crest of the teachable moment: promoting long-term health after the diagnosis of cancer. J Clin Oncol 2005;23:5814-5830.

15. Oeffinger KC. Longitudinal risk-based health care for adult survivors of childhood cancer. Curr Probl Cancer 2003;27:143-167.

16. Howlader N, Mariotto AB, Woloshin S, Schwartz LM. Providing clinicians and patients with actual prognosis: cancer in the context of competing causes of death. J Natl Cancer Inst Monogr 2014;2014:255-264.

17. Sarfati D, Koczwara B, Jackson C. The impact of comorbidity on cancer and its treatment. CA Cancer J Clin 2016;66:337-350.

18. Edwards BK, Noone AM, Mariotto AB, et al. Annual Report to the Nation on the status of cancer, 1975-2010, featuring prevalence of comorbidity and impact on survival among persons with lung, colorectal, breast or prostate cancer. Cancer 2014;120:1290-1314.

19. Oeffinger KC, Mertens AC, Hudson MM, et al. Health care of young adult survivors of childhood cancer: a report from the Childhood Cancer Survivor Study. Ann Fam Med 2004;2:61-70.

20. Armstrong GT, Kawashima T, Leisenring W, et al. Aging and risk of severe, disabling, life-threatening, and fatal events in the childhood cancer survivor study. J Clin Oncol 2014;32:1218-1227.
21. Diller L, Chow EJ, Gurney JG, et al. Chronic disease in the Childhood Cancer Survivor Study cohort: a review of published findings. J Clin Oncol 2009;27:2339-2355.

22. Cupit-Link MC, Kirkland JL, Ness KK, et al. Biology of premature ageing in survivors of cancer. ESMO Open 2017;2:e000250.

23. Smith SM, Wallace E, O'Dowd T, Fortin M. Interventions for improving outcomes in patients with multimorbidity in primary care and community settings. Cochrane Database Syst Rev 2016;3:CD006560.

24. Buffel du Vaure C, Ravaud P, Baron G, et al. Potential workload in applying clinical practice guidelines for patients with chronic conditions and multimorbidity: a systematic analysis. BMJ Open 2016;6:e010119.

25. Boyd CM, Darer J, Boult C, et al. Clinical practice guidelines and quality of care for older patients with multiple comorbid diseases: implications for pay for performance. JAMA 2005;294:716-724.

26. Muche-Borowski C, Lühmann D, Schäfer I, et al. Development of a meta-algorithm for guiding primary care encounters for patients with multimorbidity using evidence-based and case-based guideline development methodology. BMJ Open 2017;7:e015478.

27. Hawkins $N$, Smith $T$, Zhao L, et al. Health-related behavior change after cancer: results of the American Cancer Society's studies of cancer survivors (SCS). J Cancer Surviv 2010;4:20-32.

28. Underwood J, Townsend J, Stewart S, et al. Surveillance of demographic characteristics and health behaviors among adult cancer survivorsBehavioral Risk Factor Surveillance System, United States, 2009. MMWR Surveill Summ 2012;61:1-23.

29. Williams K, Steptoe A, Wardle J. Is a cancer diagnosis a trigger for health behaviour change? Findings from a prospective, population-based study. $\mathrm{Br}$ J Cancer 2013;108:2407-2412.

30. Coups E, Ostroff J. A population-based estimate of the prevalence of behavioral risk factors among adult cancer survivors and noncancer controls. Prev Med 2005;40:702-711.

31. Williams K, Beeken RJ, Wardle J. Health behaviour advice to cancer patients: the perspective of social network members. Br J Cancer 2013;108:831-835.

32. Haggstrom D, Arora N, Helft P, et al. Follow-up care delivery among colorectal cancer survivors most often seen by primary and subspecialty care physicians. J Gen Intern Med 2009;24:472-479.

33. Kenzik K, Pisu M, Fouad MN, Martin MY. Are long-term cancer survivors and physicians discussing health promotion and healthy behaviors? J Cancer Surviv 2016;10:271-279.

34. Kremer LC, Mulder RL, Oeffinger KC, et al. A worldwide collaboration to harmonize guidelines for the long-term follow-up of childhood and young adult cancer survivors: a report from the International Late Effects of Childhood Cancer Guideline Harmonization Group. Pediatr Blood Cancer 2013;60:543-549.

35. Landier W, Bhatia S, Eshelman DA, et al. Development of risk-based guidelines for pediatric cancer survivors: the Children's Oncology Group long-term follow-up guidelines from the Children's Oncology Group Late Effects Committee and Nursing Discipline. J Clin Oncol 2004;22:4979_ 4990.

36. Denlinger CS, Sanft T, Baker KS, et al. NCCN Clinical Practice Guidelines in Oncology: Survivorship. Version 1.2018. Accessed September 14, 2018. To view the most recent version of these guidelines, visit NCCN.org.

37. Schmitz KH, Courneya KS, Matthews C, et al. American College of Sports Medicine roundtable on exercise guidelines for cancer survivors. Med Sci Sports Exerc 2010;42:1409-1426.

38. Greenlee H, DuPont-Reyes MJ, Balneaves LG, et al. Clinical practice guidelines on the evidence-based use of integrative therapies during and following breast cancer treatment. CA Cancer J Clin 2017;67:194-232.

39. Runowicz CD, Leach CR, Henry NL, et al. American Cancer Society/ American Society of Clinical Oncology breast cancer survivorship care guideline. J Clin Oncol 2016;34:611-635. 
40. Cohen EE, LaMonte SJ, Erb NL, et al. American Cancer Society head and neck cancer survivorship care guideline. CA Cancer J Clin 2016;66:203239.

41. Armenian $\mathrm{SH}$, Lacchetti $\mathrm{C}$, Barac $\mathrm{A}$, et al. Prevention and monitoring of cardiac dysfunction in survivors of adult cancers: American Society of Clinical Oncology clinical practice guideline. J Clin Oncol 2017;35:893_ 911.

42. Dossett LA, Hudson JN, Morris AM, et al. The primary care provider (PCP)-cancer specialist relationship: a systematic review and mixedmethods meta-synthesis. CA Cancer J Clin 2017;67:156-169.

43. Potosky AL, Han PK, Rowland J, et al. Differences between primary care physicians' and oncologists' knowledge, attitudes and practices regarding the care of cancer survivors. J Gen Intern Med 2011;26:1403-1410.

44. Luctkar-Flude M, Aiken A, McColl MA, et al. Are primary care providers implementing evidence-based care for breast cancer survivors? Can Fam Physician 2015;61:978-984.

45. Ganz PA. Monitoring the physical health of cancer survivors: a survivorship-focused medical history. J Clin Oncol 2006;24:5105-5111.

46. Mehta LS, Watson KE, Barac A, et al. Cardiovascular disease and breast cancer: where these entities intersect: a scientific statement from the American Heart Association. Circulation 2018;137:e30-66.

47. Nishimura R, Otto C, Bonow R, et al. 2017 AHA/ACC focused update of the 2014 AHA/ACC guideline for the management of patients with valvular heart disease. J Am Coll Cardiol 2017;70:252-289.

48. Hamo CE, Bloom MW, Cardinale D, et al. Cancer therapy-related cardiac dysfunction and heart failure: part 2: prevention, treatment, guidelines, and future directions. Circ Heart Fail 2016;9:e002843.

49. Siu AL; on behalf of the U.S. Preventive Services Task Force. Screening for high blood pressure in adults: U.S. Preventive Services Task Force recommendation statement. Ann Intern Med 2015;163:778-786.
50. Whelton PK, Carey RM, Aronow WS, et al. 2017 ACC/AHA/AAPA/ ABC/ACPM/AGS/APhA/ASH/ASPC/NMA/PCNA guideline for the prevention, detection, evaluation, and management of high blood pressure in adults: a report of the American College of Cardiology/American Heart Association task force on clinical practice guidelines. Hypertension 2018;71:e13-115.

51. American College of Obstetricians and Gynecologists. Annual Women's Health Care, Ages 40-64 Years: Screening. Available at: https://www.acog. org/About-ACOG/ACOG-Departments/Annual-Womens-Health-Care/ Well-Woman-Recommendations/Screening-Ages-40-64-Years. Accessed September 14, 2018.

52. American Academy of Family Physicians. Clinical Preventive Service Recommendation: Hypertension. Available at: https://www.aafp.org/ patient-care/clinical-recommendations/all/hypertension.html. Accessed September 14, 2018.

53. Chobanian AV, Bakris GL, Black HR, et al. Seventh report of the Joint National Committee on prevention, detection, evaluation, and treatment of high blood pressure. Hypertension 2003;42:1206-1252.

54. James PA, Oparil S, Carter BL, et al. 2014 evidence-based guideline for the management of high blood pressure in adults: report from the panel members appointed to the Eighth Joint National Committee (JNC 8). JAMA 2014;311:507-520.

55. Karmali KN, Lloyd-Jones DM, van der Leeuw J, et al. Blood pressure lowering treatment strategies based on cardiovascular risk versus blood pressure: a meta-analysis of individual participant data. PLoS Med 2018;15:e1002538

56. Cifu AS, Davis AM. Prevention, detection, evaluation, and managemen of high blood pressure in adults. JAMA 2017:318:2132-2134=

\section{New address as of October 1, 2018}

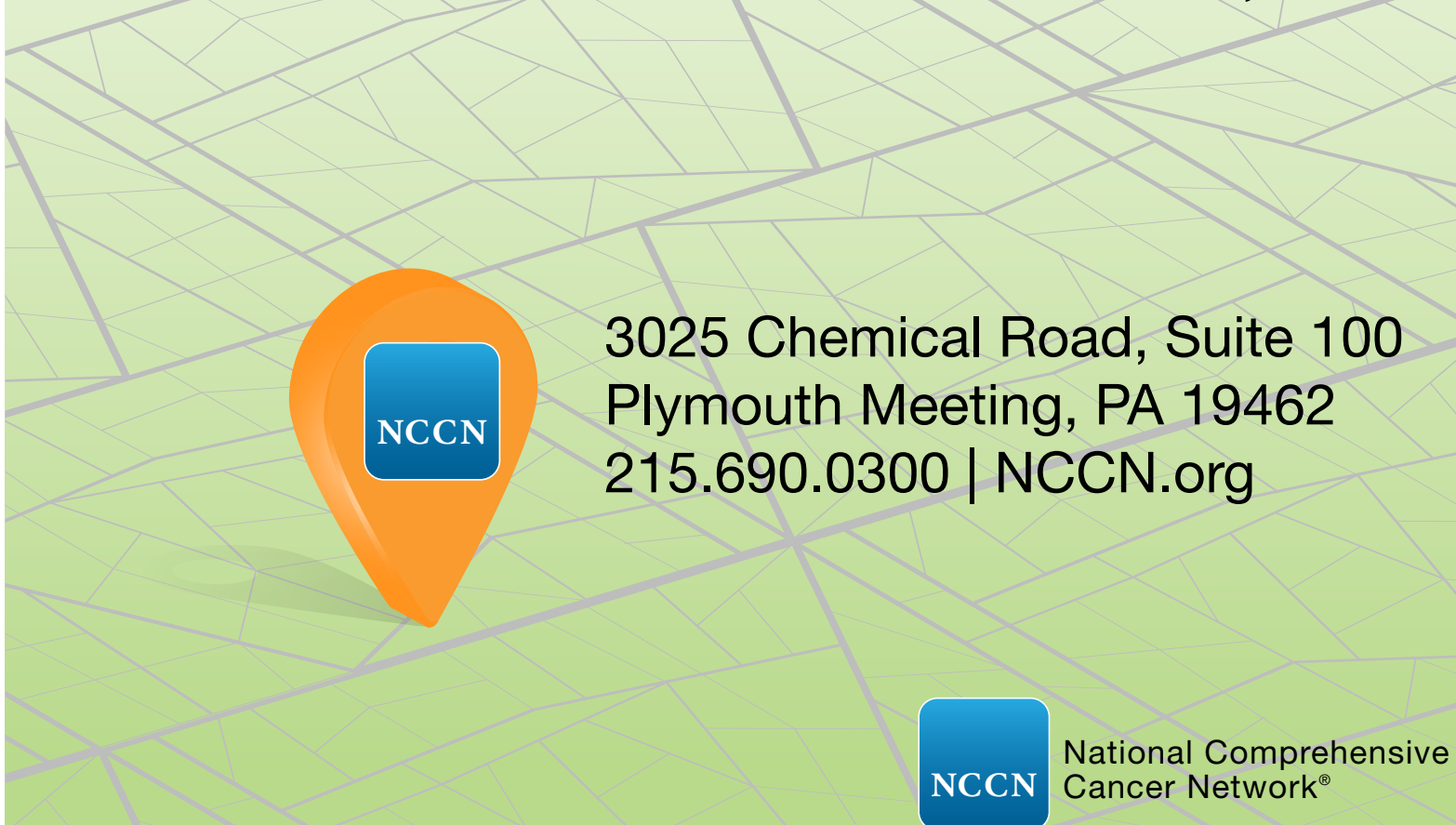

